\title{
Neolithic Occupation of Svratka Alluvial Plain; Case Study from Brno-Př́zréenice, Czech Republic
}

\author{
David Parma ${ }^{\mathrm{a}}$, Lenka Vejrostováb ${ }^{\mathrm{b}}$, Lenka Lisác ${ }^{*}$, Aleš Bajer ${ }^{\mathrm{d}}$, Jan Pacina ${ }^{\mathrm{e}}$, Zdeněk Gottvald $^{\mathrm{d}}$ \\ aArchaeological Heritage Institute Brno, Kaloudova 30, 61400 Brno, Czech Republic \\ ${ }^{b}$ Department of Physical Geography and Geoecology, Faculty of Sciences, Charles University in Prague, Albertov 6, 12843 Praha 2 , Czech Republic \\ 'Institute of Geology, The Academy of Sciences of the Czech Republic, Rozvojová 269, 16500 Praha 6, Czech Republic \\ ${ }^{d}$ Department of Geology and Pedology, Faculty of Forestry and Wood Technology, Mendel University in Brno, Zemédělská 3, 613 00 Brno, Czech Republic \\ ${ }^{e}$ Department of Informatics and Geoinformatics, Faculty of Environment, J. E. Purkyně University in Ústí nad Labem, Králova výšina 7. \\ 40096 Ústi nad Labem, Czech Republic
}

\section{ARTICLE INFO}

\section{Article history:}

Received: $23^{\text {rd }}$ June 2015

Accepted: $20^{\text {th }}$ November 2015

\section{Key words:}

Alluvial zone

buried soils

prehistoric occupation

dark earth

geoarchaeology

micromorphology

grain size analysis

magnetic proxies

\begin{abstract}
A BSTRACT
The study of paleosols, including buried soil horizons, is one of the tools used for understanding the environmental record of the past. Soil development is influenced by climate, time of development, background geology, hydrological conditions and intensity of biological decomposition. Construction works undertaken from 2012 to 2013 in the locality of in Brno-Přrizřenice, Czech Republic, situated in the inundation zone of the Svratka River, had uncovered some interesting situations in the context of the past occupation of this area. The more than 300-cm-thick section is mostly composed of alluvial deposits of the Svratka River; the base of the section is composed of stagnosols. Fluvisols were recorded in the upper part of the section and its uppermost part has signs of intensively-cultivated soil. In between these two types of soils, approximately $200 \mathrm{~cm}$ below the surface, a dark horizon representing "dark earth" was detected. The approximately $50-\mathrm{cm}$-thick dark horizon contains artefacts dated to the Neolithic, Eneolithic (Copper Age) and the Bronze Age. The locality is important for two main reasons. The first is its position in the alluvial zone. This part of the inundation zone was not flooded at least during the period between the end of the Neolithic and the beginning of the Bronze Age. This fact documents the changes in alluvial aggradations similar to that which we know from the Morava River. These changes are interpreted as being the consequence of human impact, or less likely due to climatic change. The second reason making this locality important is the appearance of the dark earth. The number and state of the archaeological remains preserved within this layer suggest the area's long-term occupation and agricultural use with fertilisation.
\end{abstract}

\section{Introduction}

Paleopedology, including the study of buried soil horizons, is a powerful way to understand the environmental record of the past. Thanks to this environmental archive it is possible to obtain various data about the environment and the pedogenic processes at the time of a soil's formation (Retallack 1988). A soil's development is influenced by the climate, location, time, parent material and topography, organisms (including intensity of biological decomposition), and a consequential variety of connected features, such as hydrological conditions (Birkeland 1975). Humans may also play an important role

*Corresponding author. E-mail: lisa@gli.cas.cz in prehistoric soil development as well (Retallack 2001). The studies of Neolithic buried soils, for example, under tumuli or ramparts, have already brought much interesting information (Hejcman, Gojda 2013; Barczi et al. 2006; 2009; Breuning-Madsen et al. 2009; Andrews, Fernandez-Jalvo 2012) about former landscapes. Comparison studies between buried and recent soils may answer questions connected with the past soil environment - as well as questions connected with the intensity of the anthropogenic impact (Wells 2000; Dreibrodt et al. 2009; Elberling et al. 2010; Horák, Hejcman 2013). During the last few decades the term "dark earth" has started to be commonly used. The term does not correspond to a soil classification name (for example, in soil taxonomy, FAO/WRB, etc.) nor should it imply a univocal archaeological interpretation. This term is used in 


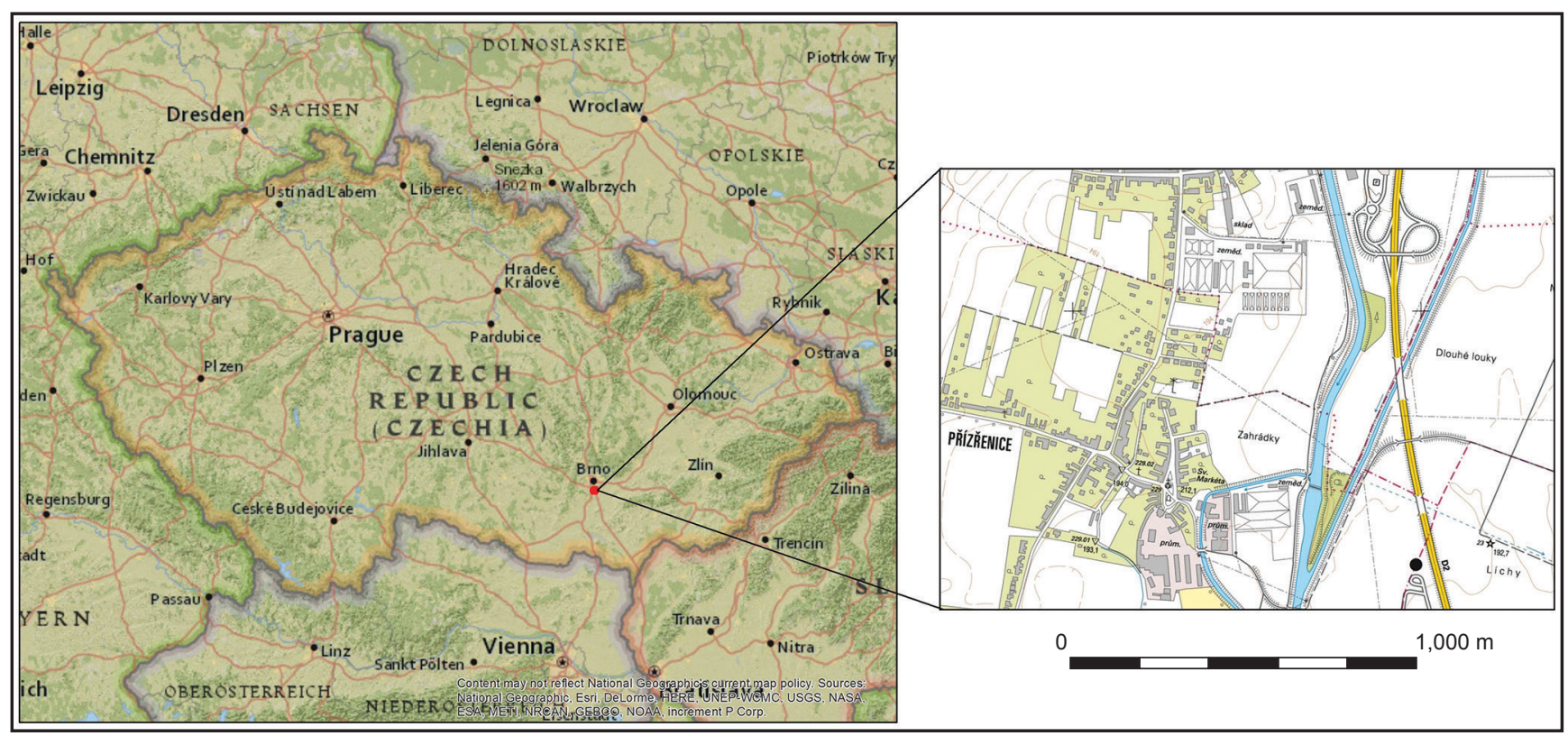

Figure 1. Location of the study site in Brno-Př́ż̌renice (overview map: Esri; detailed map: ČÚZK).

substitution for other terms present in older literature that point to the "black coloured soil" of non-identifiable origin. The term "dark earth" indicates dark-coloured, humic, and poorly stratified units, often formed over several centuries, and frequently rich in the anthropogenic remains (brick, mortar, tile, charcoal, bone, pottery, etc.) that are observed in urban contexts (Devos 2014).

The construction works in the locality of Brno-Přízrenice, in South Moravia, that are discussed in this paper were undertaken between 2012 and 2013. The locality of Přízrenice is situated in the inundation zone of the Svratka River. An interesting situation in the context of the area's past occupation was uncovered during the construction work (Parma 2013). A dark horizon, about 50-60 cm thick, containing Neolithic, Eneolithic, and Bronze Age artefacts, was excavated below the approximately $190 \mathrm{~cm}$ thick surface layer of alluvial deposits, in the centre of the recent alluvial zone of the Svratka river. When anthropogenic constituents of any size (artefacts or micro-artefacts) occur in a sedimentary matrix that shows only a microstructure created by natural processes, then the former existence of human structured micro-facies can be envisioned (Gé 1993). Micromorphological studies can then aim to determine whether pedological or sedimentary transformations may have caused the total destruction of the original structure of human origin.

Therefore, the following aims of this paper are:

$1^{\text {st: }}$ to describe this quite unique situation from an archaeological point of view (settlement strategies)

$2^{\text {nd. }}$ to discuss the context of past geomorphological and climatic changes in this area

$3^{\text {rd: }}$ to estimate the possible impact of human activities on the development of the dark horizon (possibly "dark earth") buried in the alluvial plain.

\section{Geomorphological settings}

The study site Brno-Přízrenice is located on the boundary between two cadastral territories: Brno-Př́zřrenice and Modřice. These locations, known as "Líchy" and "Na lukách", are situated in the flat alluvial plain of the Svratka River, approximately 300 metres from the recently-regulated riverbed (Figure 1). The terrain nowadays is rather different from the prehistoric one: it has been elevated and levelled since no later than the High Middle Ages. The study area is situated approximately in the centre of the recent alluvial plain (Figure 2). The position of the locality can be studied on maps of the First, Second and Third Military Surveys (Figure 2), which show changes in the extent of the alluvial plain. The Third Military Survey (1870-1880) shows nearly the same information as it is today, because at that time the riverbed of the Svratka had already been regulated. The Second Military Survey (1819-1858) shows a slight shift of the Svratka riverbed towards the west. The maps also give information about the different kinds of agricultural management at the site; the changes in agricultural management are most likely to be connected with the higher underground water level. However, the most interesting is the First Military Survey (1760-1780). Though the riverbed's position remains approximately the same as on the Second Military Survey map, nevertheless significant differences can be seen. A bridged former channel can be found in the western part of the alluvial zone in the residential area of Př́zrzrenice. The site's land cover is very different in the later map - during the time of the First Military Survey mapping there was an area of forest margin covered by trees. There is no reliable evidence of a settlement older than Medieval in the flatland of the Svratka and the Svitava river confluence, most likely due to the super-imposed younger flood sediments. Prehistoric 


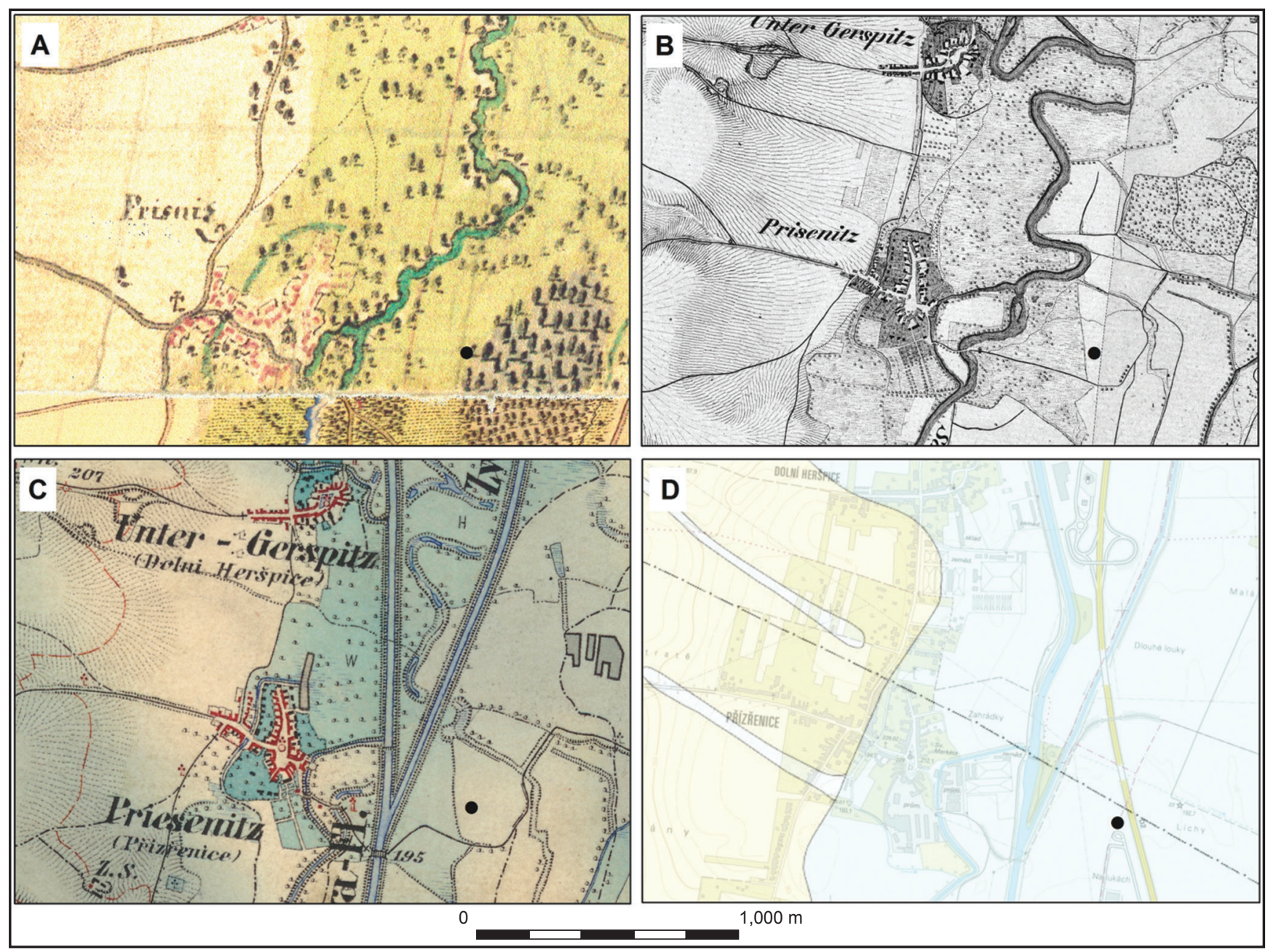

Figure 2. The historical Military Surveys (after http://oldmaps.geolab.cz). A - the $1^{\text {st }}$ Military Survey; B - the $2^{\text {nd }}$ Military Survey; C - the $3^{\text {rd }}$ Military Survey; D - geological map of the study area (after www.geology.cz); The study area is represented by the black dot.

settlement has been concentrated on its elevated borders since the Neolithic. Test pits and present-day building activities have proved the existence of remnants of buried soil and settlement layers in the floodplain (Parma 2013).

\section{Methods}

\subsection{Archaeological excavation}

The system of archaeological excavations followed the progress of the construction work. A detailed study of the sections was limited due to the construction technology used and also because of the high underground water level. The appearance of the dark horizon containing artefacts was documented from the very beginning. After precise inspection, the upper horizons composed of alluvial deposits were mechanically removed. The mechanical removal of the deposits was followed by hand digging and documentation in three trenches. In the end, an area of about 4 by 4.5 metres $\left(16.32 \mathrm{~m}^{2}\right)$ was exposed and archaeologically excavated. Investigations into the way ceramic pieces had been destroyed was crucial for our study: the appearance of more or less rounded edges or artefacts might suggest the intensity of agricultural processes. The black layer, together with contact horizons above and below, were divided into 5 equal parts, each $20 \mathrm{~cm}$ thick, such that the main bulk of the artefact-rich layer was more comprehensively studied in more detailed analyses. All the ceramic fragments, as well as all the fragments of daub, from the entire excavated volume were recovered by sieving and quantified by number of pieces and weight.

\subsection{Sedimentology and micromorphology}

It was possible to trace the study section throughout the entire construction area (minimally 50 square metres.) Because the described horizons were continuous, only one section (the best preserved) was chosen for sampling. After documentation, the 60 bulk samples were taken for chemical analyses (sampling interval of $5 \mathrm{~cm}$ ) as well as 8 micro-morphological samples $3 \times 4 \mathrm{~cm}$ in dimension. All samples were placed in small paper Kubiena boxes, dried and impregnated by Polyllite 2000 resin and then thinsectioned in the laboratory of the Institute of Geology ASCR in Prague. The standard protocol after Stoops (2003) and Bullock (1985) was used for the description. 


\subsection{Grain size distribution, magnetic proxies and $\mathrm{C}_{\text {ox }}$ measurements}

Particle size distribution was determined using a laser granulometer CILAS 1190 LD, which provides a measurement range from 0.04 to $2500 \mu \mathrm{m}$. The first measurement was made after a sample was boiled for 10 minutes in $\mathrm{KOH}$ solution to provide sufficient dispersion. The second measurement of the sample was made after carbonates were removed by boiling in $40 \%$ concentrated $\mathrm{HCl}$ for 10 minutes and any organic matter removed by the reaction with $\mathrm{H}_{2} \mathrm{O}_{2}$ (Łomotowski et al. 2008). The data in this paper are reported in three fractions: clay (up to $2 \mu \mathrm{m}$ ), silt $(2-63 \mu \mathrm{m})$ and sand $(63-2000 \mu \mathrm{m})$ (Wentworth 1922). Magnetic susceptibility was measured using an Agico MFK1FA Kappabridge at two different operating frequencies, $\mathrm{fl}=976 \mathrm{~Hz}$ and $\mathrm{f} 3=15,616 \mathrm{~Hz}$, and AC field amplitude was $200 \mathrm{~A} / \mathrm{m}$ (peak value). Readings of unconsolidated samples were taken in plastic bags. The measured susceptibility values were normalized by the mass of each sample and expressed as mass susceptibility $\left[\mathrm{m}^{3} / \mathrm{kg}\right]$. Frequencydependent magnetic susceptibility, $\mathrm{kFD}$, is characterized by the following commonly accepted parameter (Dearing et al. 1996): $\mathrm{kFD}=100 \times(\mathrm{kf1}-\mathrm{kf3}) / \mathrm{kf1}[\%]$, where $\mathrm{kf1}$ and $\mathrm{kf3}$ are the susceptibilities at frequency f1 $(976 \mathrm{~Hz})$ and frequency f3 $(15,616 \mathrm{~Hz})$, respectively. The content of soil organic carbon $\left(\mathrm{C}_{\mathrm{ox}}\right)$ was determined by rapid controlled oxidation and IR-spectrophotometry (Zbíral et al. 2004).

\subsection{Visualisation}

The visualization of the site on historical maps is presented in Figure 2. Several old maps were used in conjunction to identify the river-bank development in the past. The oldest map used was the First Military Survey of the Habsburg Empire from 1764-1768 (Figure 2A). This map was not based on any geodetic background and thus the spatial accuracy of the map is low compared to current maps. On the other hand, it provides a very unique data source as it represents the landscape more than 250 years ago. The landscape and the
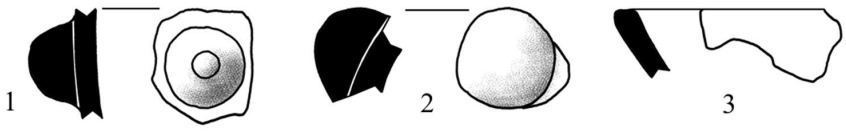

3

4
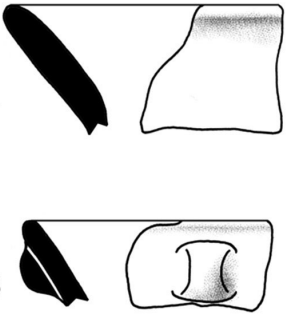

Figure 3. Representative collection of artefacts found at the site; pieces dated to the Moravian Painted Ware Culture from the end of the Neolithic (Figure 3:1-9), Early Bronze Age (Figure 3:10,11) and Late Bronze Age (Figure 3:12-13).
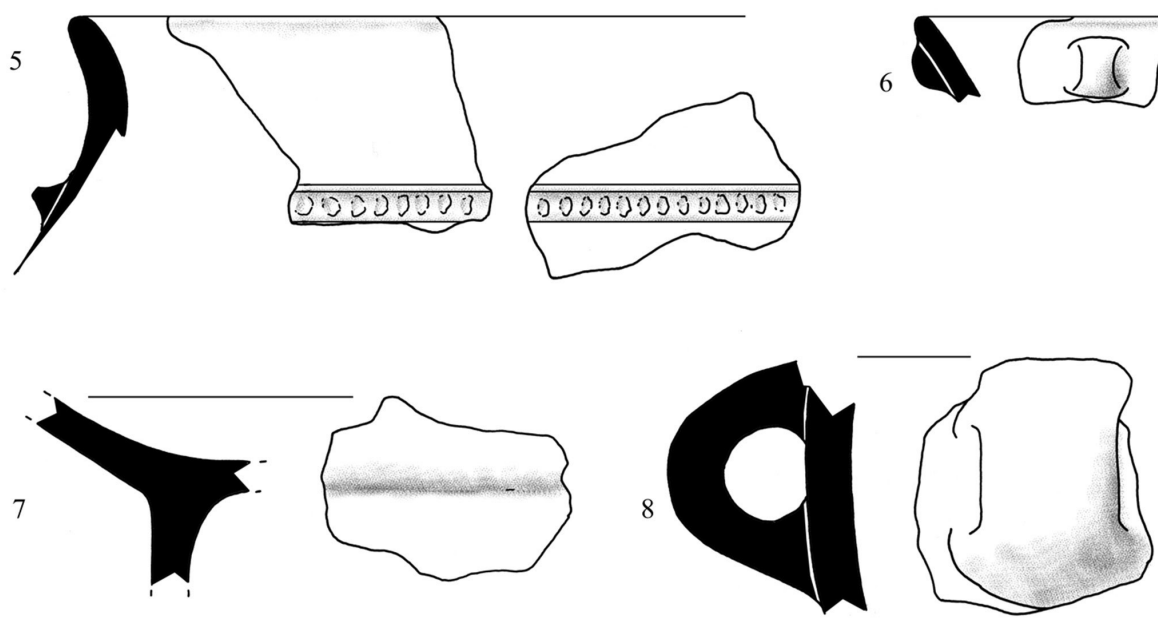

9

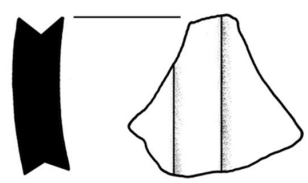

Late Neolithic Moravian Painted Ware
10

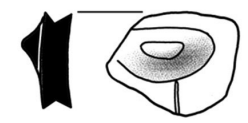

Bronze Age

Early 11

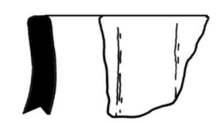

12

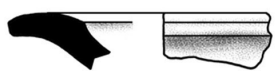

Late

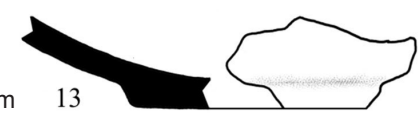


river bank development is further presented on the maps of the Second (1836-1852) and Third Military Surveys (18761878 ) presented as Figures $2 \mathrm{~B}$ and $2 \mathrm{C}$. A very important part of the workflow was the processing of these old maps: all the maps had to be georeferenced. Several methods were used for map georeferencing as each map required different handling. The Czech national S-JTSK coordinate system was used for all the maps mentioned. The most difficult was georeferencing the First Military Survey maps, as these maps were created using the 'a la vue' method (the mapper draws what he sees). An algorithm introduced by (Cajthaml 2012) was used for processing these map sheets. Maps of the Second and Third Military Survey were processed using the spline transformation implemented in ArcGIS (ESRI corp). The spline transformation is a true rubber sheeting method and is optimized for local accuracy, but not global accuracy; based on a spline function - it is a piecewise polynomial that maintains continuity and smoothness between adjacent polynomials (ESRI 2015). This method has been tested many times (Brůna et al. 2014; Pacina et al. 2014, Pacina et al. 2012) and it is considered suitable for this data type.

\section{Results of the of site research}

\subsection{Archaeological record}

The buried soil and archaeological findings were all found during excavations. The site itself is most likely located on a presumed elevation of unknown extent that has been gradually levelled by alluvial sediments. The excavations uncovered the findings and, according to the typological dating of ceramics, have been interpreted as Late Neolithic, the Early Eneolithic, and the Bronze Age. Most of the finds come from the dark layer at a depth of 190-250 cm under the recent surface. Within the layer below only a few findings (6 ceramic shards and 2 pieces of daub) were recorded, which might be regarded as secondary infiltration, for example, due to bioturbation.

During the salvage excavations a set of 544 artefacts and ecofacts (according to Neustupný terminology, without the stone findings) was excavated. The hand-made part of these excavations, covering an area of $16.32 \mathrm{~m}^{2}$, provided 388 pieces of artefacts identified as Moravian Painted Ware Culture from the end of the Neolithic, Early Bronze Age and Late Bronze Age artefacts (see Figure 3). The dark layer rich with finds was circa $65-80 \mathrm{~cm}$ thick depending on site morphology. For a more detailed stratification, the horizon was artificially divided into five parts (Table 1, Figure 4), each about $20 \mathrm{~cm}$ thick. The set of shards found at the site was quite fragmented and only $8.3 \%$ of the findings (35 pieces) were able to be archeologically dated (Table 1).

There were excavated ceramic pieces belonging to the Moravian Painted Ware Culture from the end of the Neolithic (Figure 3. 1-9), the Early Bronze Age (Figure 3:10) and from the late Bronze Age (Figure 3. 11-13). The total archaeological interval of this period is therefore approximately 4500-1000 BC. A few shards may be dated

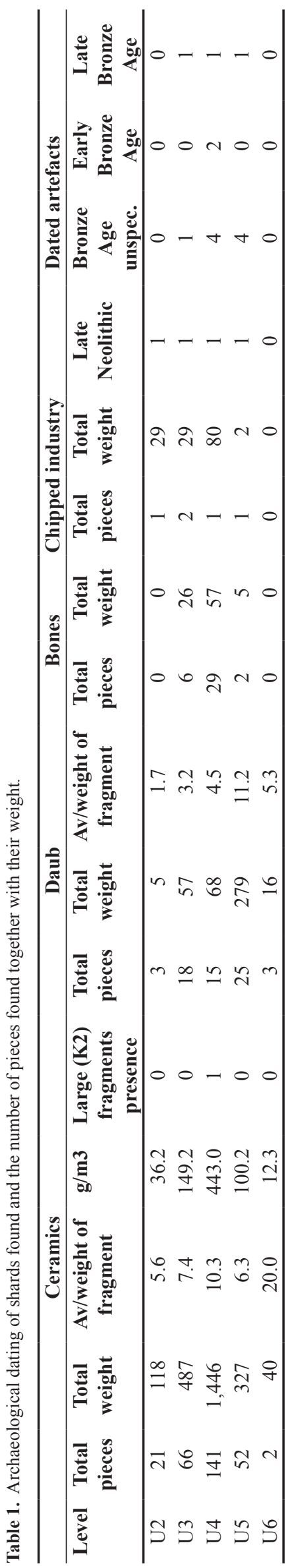




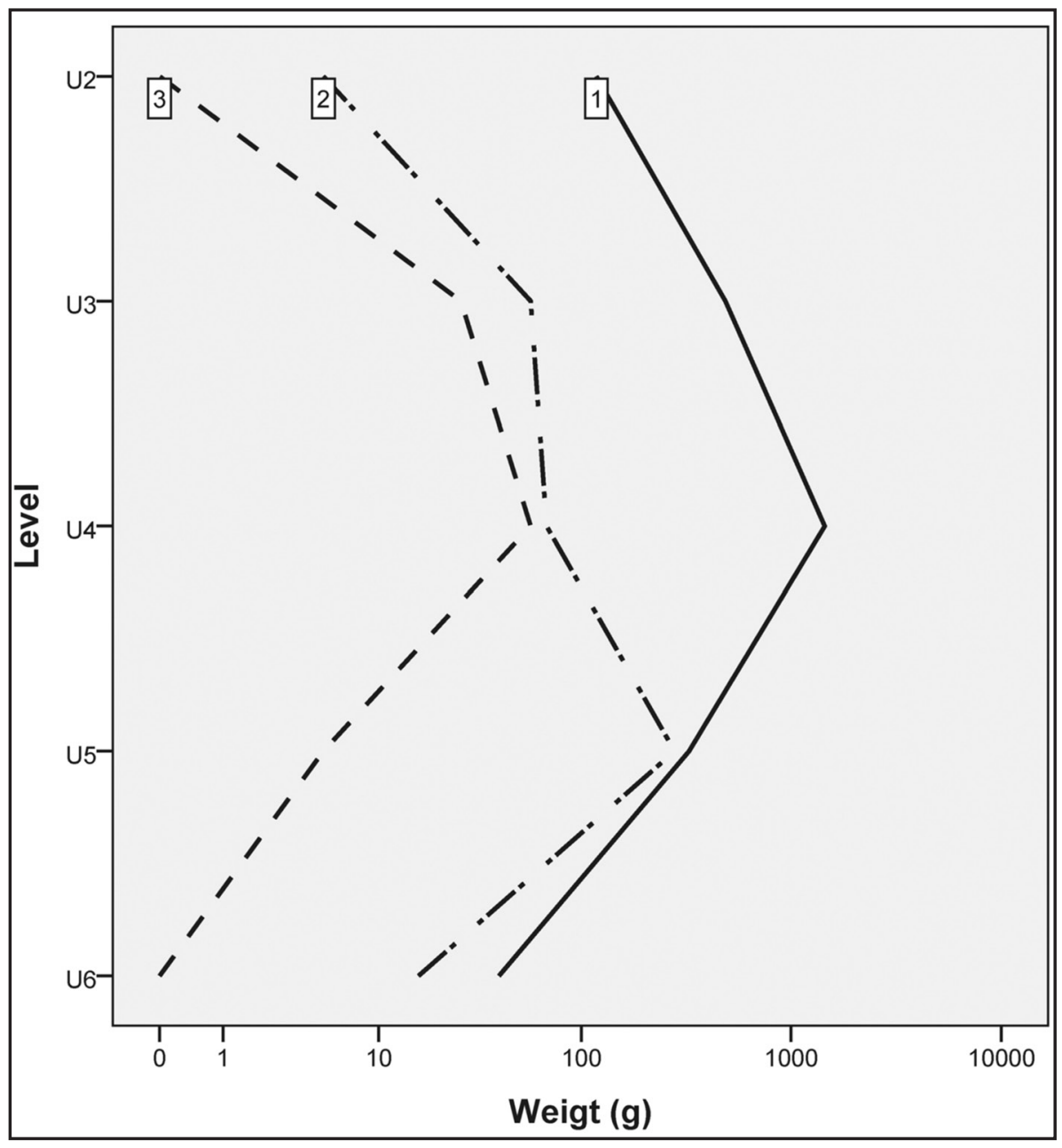

Figure 4. The frequency of the main categories of finds (weight in g) within the layer rich with finds; this layer was divided into 5 horizons (U1-U5) at steps of $20 \mathrm{~cm}$, according to man-made horizons; a logarithmic scale has been used for better comparison. U1 and U6 layers were taken from the upper and lower horizon surrounding the artefact-rich layer (horizons U2-U5); 1 - ceramics (total weight in g), 2 - daub (total weight in g), 3 - bones (total weight in $\mathrm{g})$.

as Eneolithic and also a few of them probably also into the La Tène Period. Two shards were dated as possibly Early Medieval, but this identification is not clear. Some individual shards were not found in an appropriate stratigraphical order (see Table 1); all these shards were mixed up together, which suggests an homogenisation of the studied horizon.

Most of the ceramic finds are heavily fragmented. Surprisingly, the older ones are the less fragmented. Exactly 421 pieces of ceramic totalling $3313 \mathrm{~g}$ in weight are included in the detailed description. The average weight of a single ceramic piece is $7.9 \mathrm{~g}$. The average weight of a single piece of daub is $5.6 \mathrm{~g}$ and of a single bone fragment $3.3 \mathrm{~g}$. The second size category contains only 8 pieces of total weight $440 \mathrm{~g}$ (size division according to Šabatová, Vitula 2002); the average weight of a single piece in this category is thus $55 \mathrm{~g}$. From each of the mechanically-divided horizons, $3.26 \mathrm{~m}^{3}$ of material was excavated; hence we were able to determine the average intensity of saturation by ceramic shards to be $148 \mathrm{~g} / \mathrm{m}^{3}$ with high variability (ranging from 12 to $443 \mathrm{~g} /$ $\mathrm{m}^{3}$ ). This number is quite low in comparison with similar sites, such as the Prehistorical site Záběhlice (Ernée 2008, 106), but data for older periods are as yet not available. An interesting comparison can be found in Figure 4, where the weight of the main types of finds (ceramic shards, daub, bones) are pictured depending on the depth at which they were found. The occurrence of ceramic shards and bone fragments increases in horizon 4, whilst the occurrence of daub fragments is higher within horizon 5. Even though the layer seems to be nearly homogenous, mostly due to postdepositional transformation, the changes and transitions between particular horizons are visible thanks to the artefacts; thus the change in activity at the site can be detected.

\subsection{Sedimentological and micromorphological record}

The sedimentological record was more or less continuous in all the excavated parts (Figure 5) of the construction works except the dark layer at the depth of 190-250 cm. Therefore it was possible to trace this layer horizontally throughout the whole excavated area (approximately $50 \mathrm{~m}^{2}$ ). The section with the best information value is described below:

0-25 cm: silty sand loam, dark brown, sharp transition to subsoil, bioturbation, ploughing;

25-70 cm: sandy loam, light brown, abrupt transition to underlying unit;

70-190 cm: silty loam, light brown, frequent bioturbation, worm channels, clay coatings, pseudomycelia, abrupt and wavy transition to subsoil;

190-250 cm: silty loam, dark brown, gradual wavy transition to subsoil, c. $10 \mathrm{~cm}$ thick transitional layer, worm and root textural 


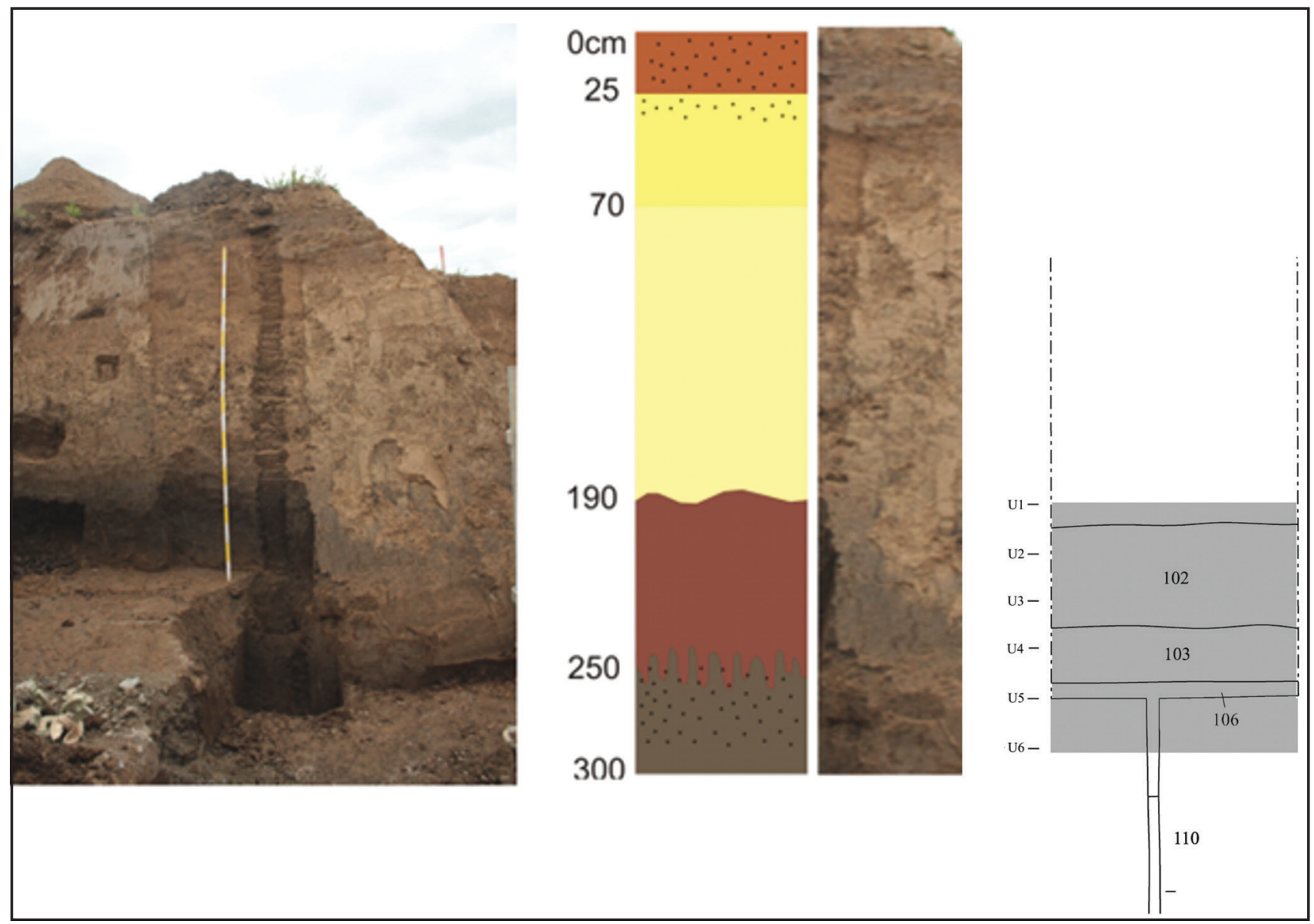

Figure 5. Sedimenthological record of the locality Brno-Př́íženice with the buried black soil at the base.

features with illuviation of $\mathrm{Fe}$ and $\mathrm{Mn}$ oxides and clay, Fe concretions;

250-300 cm: silty loam, grey brown, bioturbation by worms and roots, mixing of material from overlaying and underlying layers, 1-2 mm large concentrations of Mn (up to $5 \%$ ), greying in direction to subsoil, gley processes.

Micromorphological observations were made for each of the macroscopically-different horizons; the results are described below and photodocumentation of the main features can be found in Figure 6. The most interesting observations include the increase of the coarse fraction in the uppermost part of the section, the intensive bioturbation within the dark horizon, and the presence of Fe nodules together with $\mathrm{Mn}$ nodules in the lowermost part of the studied section.

Sample 1: Vughy microstructure, prevailing pore vughs $(20 \%)$, channels (up to $3 \%$ ). $\quad \mathrm{C}^{-\mathrm{F}_{(200 \mathrm{~mm})}}=5: 95$; $\mathrm{C} / \mathrm{F}_{(50 \mathrm{~mm})}=40: 60$. Silty loam. Prevailing provenance subangular to angular quartz and feldspar. Microcharcoal (up to $1 \%$ ), organic matter decomposed black and brown (up to $3 \%)$. Bf (birefridgence) crystallitic, light brown colour of matrix. No phytoliths, no calcium carbonates, no $\mathrm{FeOH}$ nodules. Interpretation: Mhorizon of ploughed soil.
Sample 2: Channel microstructure, prevailing pore channels $(30 \%)$, chambers (up to $3 \%) . C / \mathrm{F}_{(200 \mathrm{~mm})}=5: 95$; $\mathrm{C} / \mathrm{F}_{(50 \mathrm{~mm})}=30: 70$. Silty loam. Prevailing coarse fraction is composed of subangular to angular quartz and feldspar. Bf crystalline, brown colour of matrix. Organic matter mainly as decomposed black dots. Dirty clay coating, FeOH nodules (rare but present). $\mathrm{CaCO}_{3}$ pseudomorphoses after the root cells inside channels. Interpretation: $\mathrm{M}$ horizon.

Sample 3: Channel microstructure, prevailing pore channels $(30 \%)$, vughs (up to $3 \%) . \mathrm{C} / \mathrm{F}_{(200 \mathrm{~mm})}=3: 97 ; \mathrm{C} / \mathrm{F}_{(50 \mathrm{~mm})}=40: 60$. Silty loam. Prevailing provenance - subangular to angular quartz and feldspar. Bf crystalline to stipple speckled, brown colour of matrix. Organic matter mainly as decomposed black dots $(10 \%)$, presence of microcharcoal. Presence of FeOH nodules rare, but present. Interpretation: highly bioturbated $\mathrm{Mg}$ horizon. Sample 3 was taken from the border of two different layers, but unfortunately this fact is not reflected in the micromorphology.

Sample 4: Channel to vughy microstructure, prevailing pore channels $(20 \%)$, vughs $(10 \%) . \quad \mathrm{C} / \mathrm{F}_{(200 \mathrm{~mm})}=10: 90$; $\mathrm{C} / \mathrm{F}_{(50 \mathrm{~mm})}=50: 50$. Silty to sandy loam. Prevailing provenance - subangular to angular quartz and feldspar. Bf - crystalline, light brown to grey brown colour, Organic matter mainly as decomposed black dots. $\mathrm{FeOH}$ nodules rare but present. Interpretation: Illuviated silty to sandy $\mathrm{Mg}$ horizon, mechanically-influenced and gleyed. 


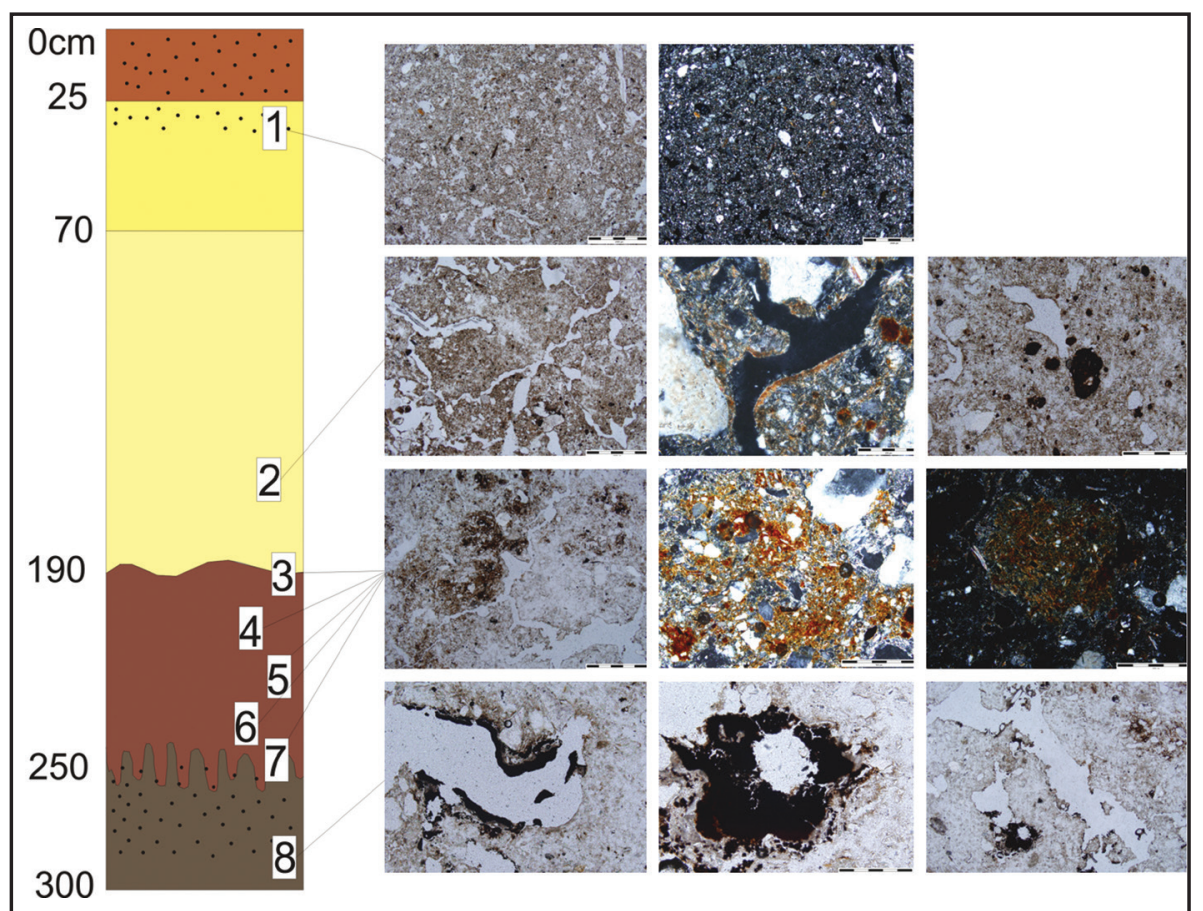

Figure 6. Photodocumentation of the micromorphological observation. Photographs connected with the sample 1 (from left to right) - vughy to channel microstructure o homogenous silty loam (first picture taken in PPL - plane polarised light; second photograph taken in XPL - cross polarised light); photographs connected with the sample 2 (from left to right) channel microstructure of homogenous silty loam (PPL); non symetrical vugh with hypocoating (XPL); $\mathrm{FeOH}$ nodules in vughy microstructure (PPL); photos connected with the samples 3 to 7 - from left to right subangluar microstructure with iluviated and alluviated parts (PPL); clay rich of $\mathrm{FeOH}$ accumulations (XPL); clay accumulations (XPL); photos connected with the sample 8 (from left to right) - vugh with Mn coating (PPL); vugh with $\mathrm{Mn}$ infilling (PPL); chamber and small vugh with Mn infilling surrounded by illuviated matrix (PPL).
Sample 5: Vughy microstructure, prevailing pore vughs $(30 \%)$, channels $(10 \%) . \mathrm{C} / \mathrm{F}_{(200 \mathrm{~mm})}=10: 90 ; \mathrm{C} / \mathrm{F}_{(50 \mathrm{~mm})}=40: 60$. Silty to sandy loam. Prevaling provenance - subangular to angular quartz and feldspar. $\mathrm{Bf}$ - crystalline, light brown to grey brown colour, Organic matter mainly as decomposed black dots. FeOH nodules, rare but present, the presence of clayey and striated matrix. Parts of matrix are more silty, other parts are more sandy and therefore went under more intensive illuviation. Dirty clay coating. Interpretation: Illuviated silty to sandy $\mathrm{Mg}$ horizon with appearance of redeposited soil material. Mechanically turbated and gleyed.

Sample 6: Subangular blocky microstructure, prevailing pore cracks (20\%), channels and vughs (up to $3 \%$ ). $\mathrm{C} / \mathrm{F}_{(200 \mathrm{~mm})}=5: 95 ; \mathrm{C} / \mathrm{F}_{(50 \mathrm{~mm})}=50: 50$. Silty loam. Prevailing provenance - subangular to angular quartz and feldspar. Bf - crystalline to stipple speckled, brown to red brown colour. Organic matter mainly as decomposed black and brown dots. FeOH nodules, rare but present; presence of clayey and striated matrix. Parts of matrix show a different grain size and Bf. Interpretation: Illuviated silty material of different provenance turbated by human action.

Sample 7: Vughy microstructure, prevailing pore vughs $(30 \%) . \quad C / F_{(200 \mathrm{~mm})}=3: 95 ; \quad \mathrm{C} / \mathrm{F}_{(50 \mathrm{~mm})}=30: 70$. Silty loam. Prevaling provenance - subangular to angular quartz and feldspar. Bf - crystalline, light brown to grey brown colour. Organic matter mainly as decomposed black dots. $\mathrm{FeOH}$ and $\mathrm{Mn}$ nodules present. Interpretation: Gleyed $\mathrm{Mg}$ horizon. Sample 7 was taken from the border of two horizons, but the differences reflected in the micromorphology are very unclear.

Sample 8: Vughy microstructure, prevailing pore vughs $(30 \%) . \quad \mathrm{C} / \mathrm{F}_{(200 \mathrm{~mm})}=3: 95 ; \quad \mathrm{C} / \mathrm{F}_{(50 \mathrm{~mm})}=30: 70$. Silty loam.
Prevailing provenance - subangular to angular quartz and feldspar. Bf - crystalline, light grey colour. Organic matter mainly as decomposed black dots. Mn nodules present, Mn coating. Interpretation: Illuviated and gleyed $\mathrm{Mg}$ horizon.

\subsection{Grain size distribution, magnetic proxies and $\mathrm{C}_{\text {org }}$}

The grain size distribution was measured in different types of dispersions with the aim of trying to obtain the most appropriate information concerning formation processes; the results are shown in Figure 7 . The most significant differences concern the distribution of the clay fraction. A significant increase of clay-fraction content was found in samples treated by $\mathrm{KOH}$ and taken from a depth of 50-80 cm, while the same set of samples treated by $\mathrm{HCl}$ and $\mathrm{H}_{2} \mathrm{O}_{2}$ showed a significant increase of clay fraction at a depth of 190-300 cm. The distribution of the sand fraction was also interesting. While the samples treated by $\mathrm{KOH}$ showed increased values of the sand-fraction content between the depth 70-190 cm and the lowermost values within the dark layer (depth 190-250 cm), the same samples treated by $\mathrm{HCl}$ and $\mathrm{H}_{2} \mathrm{O}_{2}$ showed the highest values from the surface down to a depth of $70 \mathrm{~cm}$. Another two peaks with higher values of the sand fraction were detected at the depths of 190 and $250 \mathrm{~cm}$. These peaks are probably connected with iluviation or human influence.

The values of magnetic susceptibility (Figure 7) are quite homogenous, with a slight enhancement in the uppermost layers of the studied section (depth $0-30 \mathrm{~cm}$ ). The values of frequency-dependent magnetic susceptibility show more significant differences between the studied horizons; these values usually reflect more intensive pedogenetic processes. The values within the dark horizon, mainly at the depths of 


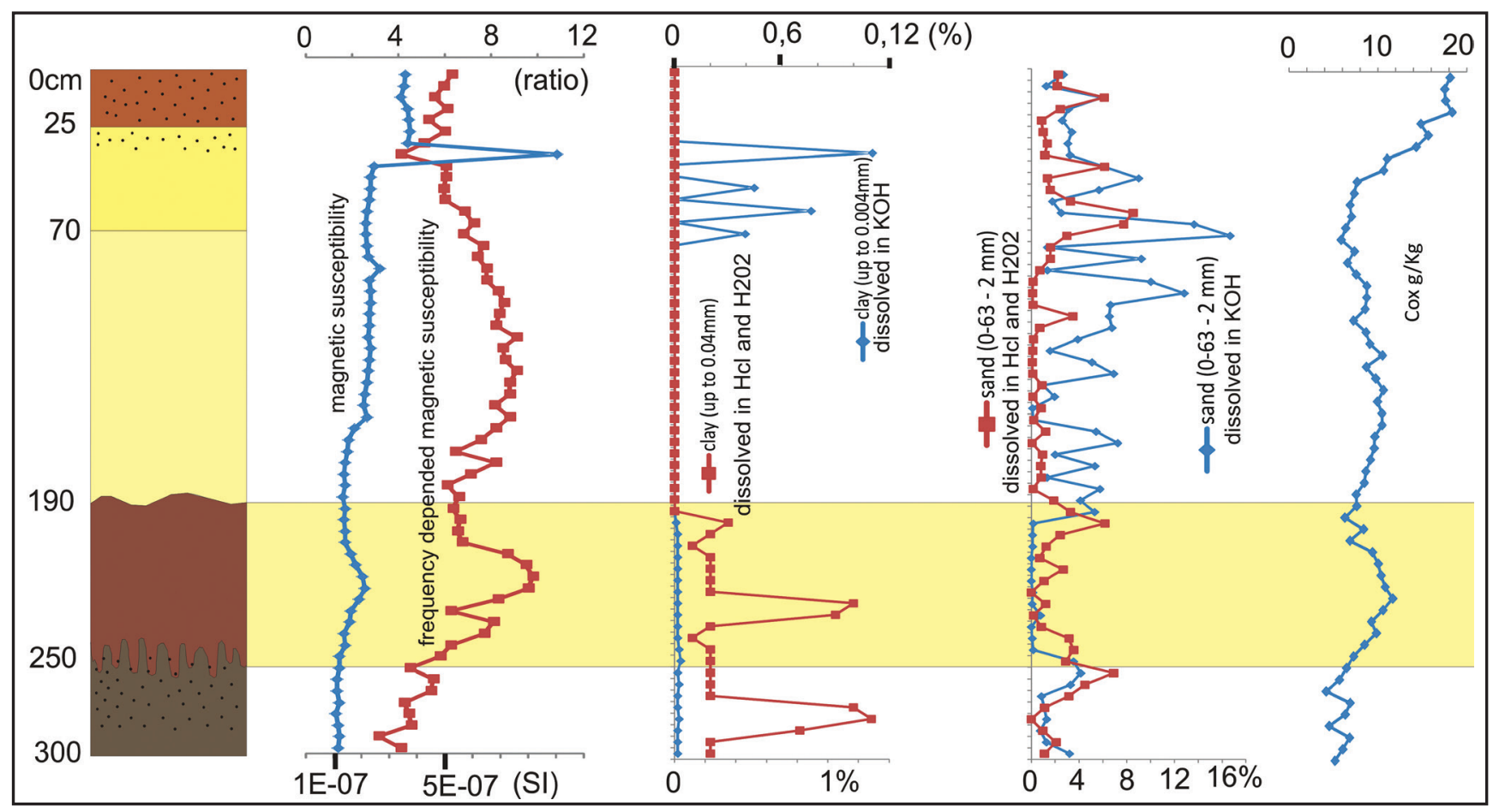

Figure 7. Values of different proxies measured in study section.

200-230 cm, are visibly enhanced, reaching nearly $11 \%$. Other enhanced values were found within the homogenous central part of the studied section, but these values reach no more than $8 \%$. The lower values within the uppermost part of the section are also of interest, because of their opposite trend of a slight increase in most of the values towards the recent surface.

The values of organic carbon $\left(\mathrm{C}_{\text {ox }}\right)$ might suggest the presence of organic matter connected with pedogenetical processes, the values correlating with the values of frequencydependent magnetic susceptibility. The first higher peak is visible within the black horizon at the depth of 200-230 cm; the second one, though not as significant, is visible in the central part of a quite monotonous alluvial sedimentation (c. 90-150 cm); and the third peak, or rather an increased trend in these values, is visible within the uppermost part of the studied section.

\section{Discussion}

\subsection{Svratka alluvial plain as a part of the living space}

The environment of the alluvial plain is a key source of archaeological information with enormous interpretative potential. The high sedimentation rates have allowed the preservation of archaeological situations (e.g. buried soil horizons or organic artefacts) to be preserved with little or no change. On the other hand, these sites are not easy to find and be investigated to a satisfactory extent. Besides the technical predicaments, the research is frequently complicated by difficulties with the site's archaeological interpretation and its chronology. Extreme caution in interpretation is needed due to the presence of redeposited artefacts and their absolute dating. The significance of well-dated situations is therefore enormous, a critical approach to all data crucial, and consideration of various interpretative alternatives necessary.

The dark earth in Brno - Prrízřence is definitely neither of wash-out origin nor of flood origin, because of the unsorted sedimentary material. The unsorted material might suggest colluvial formation, but the layers are horizontal and the flat geomorphology of the site exclude colluvial deposition. Regarding the extent of the dark earth layer and longterm stable development with no signs of flooding, it is highly improbable that this layer be considered an infilling by features of extensive origin. The provenance of the dark layer's material compares to that of the background lithology, and the lobe-like transition of the dark earth and its underlying layer strongly support the idea of it being an in situ layer that developed on flood sediments thanks to pedogenic processes.

The existence of this type of sediment in situ indicates the close proximity of long-term inhabitation in the Late Neolithic, Early Eneolithic, and Bronze Age (4500-1000 BC). In general, prehistoric settlement is concentrated in the surroundings of large rivers, because this environment can allow several alternative farming strategies, such as: different ways of fertilisation, irrigation or differing crop production depending on water availability. On the other hand, this way of thinking only works in certain prehistoric periods ( $c f$. in the Labe - Elbe Valley Dreslerová, Pokorný 2004) and for certain regions. In the valley of the Svratka River, south of Brno, for example, the known prehistoric settlement is primarily concentrated on the edges 
of terraces ( $c f$. the archaeological topography of the cadastral territories of Brno-Chrlice and Brno-Horní Heršpice in Procházka ed. 2011). A similar situation can be found in the alluvial plains of the Morava and Dyje Rivers, where sand dunes were systematically chosen for settlement (Dresler, Macháček 2013, 690-698; Dresler 2014); the dunes can be easily examined and basic trends in prehistoric settlement can be described. The absence of a sandy background in the study area excludes such a possibility in Brno-Přížrenice, and there is insufficient information about the lower course of the Svratka River. However, the local alluvium was used by human settlers, a fact proved by the existence of another settlement and graveyard of Late Bronze Age origin; it was discovered during construction work in 1953 in Brno-Chrlice approximately $1.5 \mathrm{~km}$ from our locality. The prehistoric cultural layer at that site was covered by a $1.4 \mathrm{~m}$ thick layer of alluvial sediments (Staňa 1957).

\subsection{Aggradation of the Svratka alluvial deposits in the context of prehistoric occupation}

The widespread assumption, supported by the latest research results in the Morava river basin, is that the typical silty alluvial sediments, such as these in the Svratka river alluvial zone, did not aggradate until the last 1000 years (Kadlec 2009; Grygar 2010). The hypothesis is based on the finding of several dendrochronologically-dated tree trunks at the base of the recent floodplain/alluvial zone; the time span, therefore, could be even shorter. However, sheet erosion (the consequence of intensive human activity in a landscape) is a phenomenon that has been traced to the Neolithic in central Europe (Dreibrodt et al. 2010). We do not have direct evidence from the Svratka valley; nevertheless, we assume that both the Morava and Svratka catchments are comparable: being located in the same region and of similar size of catchment.

The crucial dilemma is whether the aggradation was caused by human activity, climate change, or both. This has been much discussed over a long period (Kadlec et al. 2009; Grygar 2010; Opravil 1985) and it is generally accepted that in the case of a significant part of a catchment being part of an old settlement area, the changes in intensity and methods of management have directly influenced the alluvial zone. The regional impact of human activity on flood plain evolution has already been recognized by several authors, who have stated that an oak forest clearance in the vicinity of a river causes changes in flood activity and increases deposition within the flood plain (Prudič 1978; Opravil 1983; Svobodová 1989; Havlíček 1991). Another hypothesis, which is based more on natural processes, suggests that the activity of rivers in Europe were probably developed in cycles more closely linked to climate change than to local anthropogenic activity (Starkel 2002; Macklin et al. 2005; Lewin et al. 2005; Thorndycraft, Benito 2006; Starkel et al. 2006; Kalicki 2006). Regarding the above-described hypotheses, the question of global vs. regional climatic trends and their impact has also been a topic for discussion, as well as the possible decisive impact of singular events (e.g.
Dreslerová in 2012 describes an increase in precipitation in c. $2000 \mathrm{BC}$ according to a statistical model).

The increase in aggradation of the floodplain has not yet been synchronized precisely with the increased precipitation. All things considered, there is the possibility that the difference between precipitation and type of climate in central Europe is not large enough to cause sheet erosion, and the aggradation is of anthropogenic origin. The settlement is more or less in the central part of the alluvial zone (Figure 2), and the increased aggradation by alluvial sediment would probably lead to a rapid covering of the site. On the other hand, the studied site does not show any sign of occasional flooding, which would indicate flooding after the settlement had been abandoned.

Reliably-intact archaeological sites may be important points of reference in the study of very dynamic alluvial environments, where the shifting of channels is commonplace and therefore redeposited sediments and artefacts would be common as well. The described site, BrnoPř́zřenice, contains an in situ occupational level formation that consequently represents evidence of long-term soil development and use of the site for settlement purposes from the Neolithic to Bronze Age (4500-1000 BC), and which was subsequently covered by alluvial sediments. We have not yet dated the floodplain deposits, but by comparing with the Morava river floodplain it is possible to state that the aggradation of the flood plain in Přízrenice is not a question of a single event.

\subsection{Prehistoric dark earth and its formation processes}

The dark horizon at the site evinces characteristic features of dark earth. It is a widespread artefact-containing layer of dark colour. Dark earth does not belong to any soil classification or soil taxonomy, the term is of archaeological origin. Considering the terrain's morphology and the time of development, a Chernozem or type of Molisol could be considered the closest analogy. Chernozem soils under Late Neolithic and Bronze Age barrows have also been discovered by Barczi et al. (2006a; 2006b; 2009) in Hungary. According to Hejcman (2013), Chernozem soils, which in Prehistory had been quite extensive in central Europe, had probably degraded due to the more intensive leaching, and were replaced step by step with forest Luvisols and Albeluvisols subsequent to the Bronze Age. This hypothesis is supported by the climatic change around $2000 \mathrm{BC}$, characterised by an increase in precipitation together with a decrease in mean annual temperature in central Europe (Dreslerová 2012), leading to the leaching of base cations from soils and thus to the degradation of Chernozems. A similar result, the replacement of steppe Chernozem soils by forest Luvisols around $1000 \mathrm{BC}$, has also been recorded by Alexandrovskiy (2000) in the North Caucasus.

The very next question is: what does the dark earth represent at this site? Is it the remnants of older settlement layers that naturally homogenized into the form of a soil horizon? Are those settlement layers homogenized into the form of a soil at the end of their development, or is it a ploughed 
or plaggen soil from the very beginning and which was fertilized by the waste from the nearby settlement? The latter idea is supported by the characteristics of the archaeological finds and their scattering: when small artefacts prevail it is assumed that they were a part of the common waste that was relocated together with the surrounding sediment in the settlement area (Kuna, Němcová et al. 2012). The increased values of organic carbon, together with the enhanced frequency-dependent magnetic susceptibility signal, suggest the presence of a former A horizon together with soil bacteria producing superparamagnetic minerals (Dearing et al. 1996). On the other hand, the changes in grain size might reflect the inhomogeneity of the horizon that reflects the presence of fertiliser.

A collection of 421 fragments of total weight $3313 \mathrm{~g}$ have been described in detail. The average weight of a single piece is $7.87 \mathrm{~g}$, which corresponds very well with the average weight of a fragment from the Late Bronze Age layer formation in Praha-Záběhlice (7.9 g; Ernée 2008, 106, Table 4). However, this figure is much lower than the values for collections from infillings of sunken features from the Bronze Age (e.g. $17.9 \mathrm{~g}$ ). Also, the average weight of a daub fragment $(5.59 \mathrm{~g})$ and the average weight of a bone fragment $(3.31 \mathrm{~g})$ unambiguously indicate an enormous level of fragmentation during the post-depositional processes, probably caused by trampling underfoot or otherwise shattered. Bioturbation, which may be another factor, could not produce such strong fragmentation. There are only eight ceramic fragments of size category 2 (weight $440 \mathrm{~g}$ ) and they represent the oldest fragments found. All the fragments are Neolithic and regarding the length of duration of the transformational processes, the locality examined is probably the closest one to the central part of the Neolithic settlement area. On the other hand, the high fragmentation of younger fragments suggests that the centres of the Bronze Age settlement areas were farther away or the agricultural management was more intensive. As a conclusion it may be stated that, at the very least, during the first stage of occupation the dark earth had developed as a cultural horizon. According to Gé (1993), non-constructed occupation surfaces most generally consist of swept or dumped debris, or of construction materials collapsed from perishable buildings. They are usually easily recognized in the field by the occurrence of two distinct units overlying the debris or the collapsed infill. In many cases, the lowermost one appears as a thin compact layer, while the upper one has a weak cohesion. Moreover, the two units can often be distinguished by differences in colour and composition. But this is not the case for our studied locality; on the other hand, the signs of relict structured micro-facies, as well as possibly fragments of occupation surfaces in a tertiary position (as defined by Butzer 1982), have been identified - mainly within the central part of the dark layer.

Residual structured micro-facies are characterized by the occurrence of large aggregates detected in thin sections, with a fabric similar to zones of structured micro-facies. These are finely mixed with sedimentary material, characterized by a microstructure differing from the one induced by human trampling. This microstructure is typified by intergranular pores and the chaotic distribution of its coarse fraction. When intense bioturbation occurs, the material becomes homogenised through various homogenization processes. If the unit which contains fragments of occupation surfaces consists of loosely-packed aggregates of various anthropogenic origin, than the material was deposited either by dumping or mechanically reworked after deposition, for example, due to agricultural practices (ploughing, plugging) (Butzer 1982). Because of the long-term deposition time span detected at the Př́zŕmenice site, we suggest that the fragments of the occupation surfaces are in a tertiary position (as defined by Butzer 1982) and have consequently lost their original contextual significance - not because of dumping, but because of agricultural practices. These may represent something like midden material being used as a fertiliser. Distinguishing a dump area from that of a patch of arable land may sometimes be quite tricky. At Tofts Ness, the cultivated Neolithic soils, and, at Old Scatness, the primary soils, were nearly identical to the midden deposits found in the settlements. The evidence suggests that the arable plots were placed on top of the midden heaps, which means that the midden heaps were transformed into cultivated plots (Guttman 2004). Cultivation of a midden in the Neolithic has also been suggested by Macphail (1990) at Hazleton North, Gloucestershire, where small, shifting arable plots were recorded beneath a long cairn, and one of the plots was placed on top of a midden heap.

\section{Conclusion}

The studied site was continuously and for a long time occupied during the Late Neolithic, the Early Eneolithic, and the Bronze Age (4500-1000 BC), which implies that the site was not flooded for more than 3500 years. This fact may be more likely interpreted as a result of the limited source of alluvial deposits rather than as a consequence of climatic changes that resulted in lower precipitation for such a long period.

The dark layer buried under the two metres of alluvial deposits has been described as "dark soil/dark earth" and has signs of a leached, intensely anthropogenically-influenced, Mollisol type of soil. The statistical distribution and type of artefacts suggest that at least during the older part of the occupation the area was a part of constructed site. During the later occupation the material probably accumulated due to dumping. In every case, the fragments of occupation surfaces are in a tertiary position and homogenised. This homogenisation is due to agricultural processes followed by the intensive pedological processes which took place there. Their presence has been confirmed by a range of methods, i.e. the microstructure of the studied deposits and also by the enhanced values of frequency-dependent magnetic susceptibility, increased values of organic carbon, and changes in grain size distribution, as well as the homogenization of the archaeological material within the studied horizon. The 
accumulation of organic material within the "dark earth" is connected not only with the decomposition of vegetation, but also with the "manuring" processes connected with the former agricultural practices.

\section{Acknowledgement}

This research was supported by the Internal program of the Institute of Geology, ASCR, no. RVO 67985831, conducted under the Project Platform for Landscape Formation (Reg. No. CZ.1.07/2.4.00/31.0032) and financed by the project "PAPAVER - Centre for human and plant studies in Europe and Northern Africa in the postglacial period" project, reg. No. CZ.1.07/2.3.00/20.0289, co-financed by the European Social Fund and by the state budget of the Czech Republic.

\section{References}

ALEXANDROVSKIY, A. L. 2000: Holocene development of soils in response to environmental changes: the Novosvobodnaya archaeological site, North Caucasus. Catena 41, 237-248.

ANDREWS, P., FERNANDEZ-JALVO, Y. 2012: Bronze age barrows at Longstone Edge: taphonomy and site formation. Quaternary International 275, 43-54.

BARCZI, A., JOÓ, K., PETÓ, Á., BUCSI, T. 2006a: Survey of the buried paleosol under the Lyukas mound in Hungary. Eurasian Journal of Soil Science 39, 133-140.

BARCZI, A., TÓTH, T.M., CSANÁDI, A., SÜMEGI, P., CZINKOTA, I. 2006b: Reconstruction of the paleo-environment and soil evolution of the Csípo-halom kurgan, Hungary. Quaternary International 156-157, 49-59.

BARCZI, A., GOLYEVA, A. A., PETO, A. 2009: Palaeoenvironmental reconstruction of Hungarian kurgans on the basis of the examination of palaeosoils and phytolith analysis. Quaternary International 193, 49-60.

BIRKELAND, P. 1975: Soils and geomorphology. Oxford Press, Oxford.

BRU゚NA, V., PACINA, J., PACINA J., VAJSOVÁ E. 2014: Modeling the extinct landscape and settlement for preservation of cultural heritage. Città e Storia IX/1, 131-153.

BULlOCK, P., FEDOROFF, N., JONGERIUS, A., STOOPS, G., TURSINA, T. 1985: Handbook for Soil Thin Section Description. Waine Research Publications, Wolverhamton.

BUTZER, K. W. 1982: Archaeology as Human Ecology. Cambridge University Press, Cambridge.

CAJTHAML, J. 2012: Analysis of old mapsin digital environment on the example of Müller's map of Bohemia and Moravia. Nakladatelství ČVUT, Praha.

DEVOS, Y. 2014: Dark Earth In: Smith, C. (Ed.): Encyclopedia of Global Archaeology. Springer, 7532-7540.

DEARING, J., LIVINGSTONE, I., ZHOU, L. P. 1996: A Late Quaternary magnetic record of Tunisian Loess and its climatic significance. Geophysical Research Letters 23.

DREIBRODT, S., NELLE, O., LÜTJENS, I., MITUSOV, A., CLAUSEN, I., BORK, H. R. 2009: Investigations on buried soils and colluvial layers around Bronze Age burial mounds at Bornhöved (northern Germany): an approach to test the hypothesis of landscape openness by the incidence of colluviation. The Holocene 19, 487-497.

DREIBRODT, S., LUBOS, C., TERHORST, B., DAMM, B., BORK H.-R. 2010: Historical soil erosion by water in Germany: Scales and archives, chronology, research perspectives. Quarternary International 22, 80-95.

DRESLER, P., MACHÁČEK, J. 2013. Vývoj osídelní a kulturní krajiny dolního Podyjí v raném středověku (The history of settlement and the cultural landscape in the lower Dyje (Thaya) River region in the Early Middle Ages). Archeologické rozhledy LXV, 663-705.

DRESLER, P. 2014: Průzkum nejbližšího zázemí Pohanska u Břeclavi
(Survey in the close hinterland of Pohansko u Břeclavi). Jižni Morava 53, 350-358.

DRESLEROVÁ, D., POKORNÝ, P. 2004: Vývoj osídlení a struktury pravěké krajiny na středním Labi. Pokus o př́mé srovnání archeologické a pyloanalytické evidence (Settlement and prehistoric land-use in middle Labe valley, Central Bohemia. Direct comparison of archaeological and pollen-analytical data). Archeologické rozhledy LVI, 739-762.

ELBERLING, B., BREUNING-MADSEN, H., HINGE, H., ASMUND, G. 2010: Heavy metals in 3300-year-old agricultural soils used to assess present soil contamination. European Journal of Soil Science 61, 74-83.

ERNÉE, M. 2002: Pravěké kulturní souvrstvi jako archeologický pramen. Památky archeologické - Supplementum 20.

GÉ, T., MATTHEWS, W., WATTEZ, J. 1993: Sedimentary Formation Processes of Occupation Surfaces. In: Goldberg, P., Nash, D. T., Petraglia, M. D. (Eds.): Monographs in World Archaeology 17, 149-163.

GILBERTSON, D. D., SCHWENNINGER, J. L., KEMP, R. A. RHODES, E. J. 1999: Sand-drift and soil formation along an exposed North Atlantic coastline: 14,000 years of diverse geomorphological, climatic and human impacts. Journal of Archaeological Sciences 26, 439-69.

GUTTMAN, E. B. A., DOCKRIL, S. J., SIMSON, I. A. 2004: Arable agriculture in prehistory: new evidence from soils in the Northern Isles. Proceedings of Social Antiquity Scotland 134, 53-64.

GRYGAR T., SVĚTLÍK I., LISÁ L., KOPTÍKOVÁ L., BAJER A., WRAYE D.S., ETTLER V., MIHALJEVIČ M., NOVÁKOVÁ T., KOUBOVÁ M., NOVÁK J., MÁC̆KA Z., SMETANA Z. 2010: Geochemical tools for the stratigraphic correlation of floodplain deposits of the Morava River in Strážnické Pomoraví, Czech Republic from the last millennium. Catena 80/2, 106-121.

HAVLÍČEK P. 1991: The Morava River Basin During the Last 15000 Years. In: Starkel L. Gregory K. J., Thornes J. B. (Eds.): Temperate Palaeohydrology. Wiley and Sons Ltd., 319-341.

HEJCMAN, M., SOUČKOVÁ, K., KRIŠTUF P., PEŠKA J. 2013: What questions can be answered by chemical analysis of recent soils and paleosols from the Bell Beaker barrow (2500-2200 BC), Central Moravia, Czech Republic? Quaternary International 316, 179-189.

HORÁK, V., HEJCMAN, M. 2013: Use of trace elements from historical mining for alluvial sediment dating. Soil and Water Research 8, 77-86.

KADLEC J., GRYGAR T., SVĚTLÍK I., ETTLER V., MIHALJEVIČ M., DIEHL J. F., BESKE-DIEHL S. A., SVITAVSKÁ-SVOBODOVÁ H. 2009: Morava River floodplain development during the last millennium, Strážnické Pomoraví, Czech Republic. The Holocene 19/3, 499-509.

KUNA, M., NĚMCOVÁ, A. 2012 (Eds.): Výpovéd' sídlištního odpadu. Nálezy z pozdni doby bronzové $v$ Roztokách a otázka depozični analýzy archeologického kontextu (The evidence of settlement discard. Finds from the Final Bronze Age at Roztoky and the depositional analysis of archaeological context). Archeologický ústav, Praha.

ŁOMOTOWSKI J., BURSZTA-ADAMIAK E., KĘSZYCKA M., JARY Z. 2008: Metody $i$ techniki optyczne $w$ badaniach zawiesin. Monografie Instytutu Badań Systemowych PAN, Seria Badania Systemowe, tom 58, Warszawa.

MACHÁČEK, J. 2012: Archeologie údolní nivy aneb Proč možná zanikla Velká Morava. Vesmir 91, 566-569.

OPRAVIL, E. 1983: Údolní niva v době hradištní. Studie Archeologického ústavu ČSAV v Brně XI, 2, Archeologický ústav ČSAV v Brně, Brno.

PARMA, D. 2013: Brno-Přízřenice 2012-2013. Technické vybavení území - II. Etapa CTPark Modřice UU, k.ú. Modřice. MS. Excavation report. Deposited: Ústav archeologické památkové péče Brno.

POLÁČEK, L., HLADÍK, M. 2014: Archaeological excavation B 2012 of the filled-up riverbed and bridge No. 1 in Mikulčice. In: Poláček, L. (Ed.): Mikulčice river archaeology. New interdisciplinary research into bridge No. 1. Internationale Tagungen in Mikulčice X, 27-60.

PROCHÁZKA, R. (Ed.) 2011: Dějiny Brna 1. Od pravěku k ranému středověku. Město Brno, Brno.

PRUDIČ, Z., 1978: The Strážnice floodplain forest in the second half of the $1^{\text {st }}$ millennium A.D. Lesnictví 24, 1019-1036.

RETALLACK, G. J. 1998: Core concepts of paleopedology. In: Follmer, L. R., Johnson D. L., Catt, J. A. (Eds.): Revisitation of concepts in paleopedology (Transactions of the Second International Symposium on Paleopedology). Quaternary International 51/52, 203-212.

RETALlACK, G. J. 2001: Soils of the Past: An Introduction to Paleopedology. Wiley. 
STOOPS, G. 2003: Guidelines for Analyses and Descriptions of Soil and Regolith Thin Sections. Science Society of America, Madison.

STAŇA, Č. 1957: Časně únětické hroby a sídliště v Chrlicích u Brna, Archeologické rozhledy IX, 162-167.

SVOBODOVÁ, H., 1989: A reconstruction of natural environment and settlement in the environs of Mistř́n. A palynological study. Památky archeologické 80, 188-206.
WENTWORTH, C.K. 1922: A scale of grade and class terms for clastic sediments. Journal of Geology V.30, 377-392.

WELLS, E. C. 2000: Chemical analyses of ancient Anthrosols in residential areas at Piedras Negras, Guatemala. Journal of Archaeological Science 27, 449-462.

ZBÍRAL, J., HONSA, I., MALÝ, S., ČIŽMÁR, D. 2004: Analýza půd III. Jednotné pracovni postupy. ÚKZÚZ Brno, Brno. 
